\title{
UV Light Pan Traps for Collecting Aquatic Insects
}

\author{
Adolfo Ricardo Calor ${ }^{\bowtie} \&$ Rodolfo Mariano²
}

1.Universidade Federal da Bahia, e-mail: acalor@gmail.com (Autor para correspondência ${ }^{\varpi}$ ). 2. Universidade Estadual de Santa Cruz, e-mail: rodolfomls@gmail.com.

$$
\text { EntomoBrasilis } 5 \text { (2): 164-166 (2012) }
$$

\begin{abstract}
A simple, inexpensive light trap is described for collecting night-flying insects. The components for constructing the light trap are described and the advantages and disadvantages for collecting different taxa of aquatic insects are discussed.
\end{abstract}

Keywords: Collecting methods; light-attraction; night-flying insects.

\section{Armadilha Luminosa para Coleta de Insetos Aquáticos}

Resumo. Armadilha luminosa simples e de baixo custo é apresentada para coleta de insetos noturnos. Os componentes necessários para a construção da armadilha luminosa são descritos, assim como suas vantagens e desvantagens são discutidas.

Palavras-Chave: Atração luminosa; insetos com atividade noturna; métodos de coleta.

The entomological light trap was aparently developed to collect insects of medical importance such as mosquitoes, midges, sand flies and black flies, but its application for collecting nocturnal insects is very old (e.g., Burks et al. 1938). Nowadays, light traps are used to attract a wide variety of nocturnal flying insects and many kinds of light traps exist (PETERSON 1964; MARTIN 1977; SteYskal et al. 1986; Marshall et al. 1994; GibB \& OSETO 2006). Many are available commercially, but they can be homemade from relatively inexpensive materials. Some light traps collect the specimens alive, while others draw the insects into a killing chamber filled with cyanide crystals or a liquid preservative such as $80 \%$ ethanol.

Most aquatic insects and especially caddisflies (Trichoptera) are commonly attracted to lights, especially ultraviolet or black light, the exception being the few diurnal caddisfly species, e.g., Phylloicus species Müller (Calamoceratidae). One common practice is to hang a fluorescent black light in front of a white sheet (cloth or plastic) and to collect specimens with a killing jar or vial with alcohol after they are attracted to the light and land on the sheet. This is an active method and the ability of the collector to select individual specimens is a strong point. However, in the field this active collecting technique limits the collection to a single station, which may mean that the collector exerts a large effort, for a small result (i.e., few specimens under certain conditions).

Another approach is to use a passive methodology, by placing a lantern or fluorescent tube on or near a tray (the "pan trap" method of BLAHNik \& Holzenthal 2004) and to increase the number of collecting sites by laying out several traps at different localities. Other examples of passive light traps include the New Jersey light trap (Mulhern 1942) or CDC trap (Sudia \& Chamberlain 1962). The simplest pan light trap consists of a system to illuminate (generally a fluorescent tube) and a collecting recipient with alcohol or other preserving fluid at the bottom. The insects attracted by the light are traped and quickly succumb in the alcohol. Of course, the light must be placed within a few centimeters (no more than $10 \mathrm{~cm}$ or so) of the fluid. If the focus is on aquatic insects, the best place to run this trap is directly adjacent to any water body (e.g., streams or lakes).

The light pan trap described here operates from $12 \mathrm{~V}$ batteries, which power a fluorescent daylight bulb $(15 \mathrm{~W} / 12 \mathrm{~V})$ and a UV bulb $(15 \mathrm{~W} / 12 \mathrm{~V})$, and one or two electronic ballast for the fluorescent lamps (Figure 1). The use of electronic ballast makes this pan trap small and inexpensive. An alternative is inverters to convert the $\mathrm{DC}$ current from the battery to AC current to supply power to the common ballast $(127 \mathrm{~V})$, which decrease the efficiency and consequently the battery's lifetime.

The nominal current of the battery (fully charged), the current drawn by the lights and from the electronic ballast will determine how long the light(s) will run. For example, a 45Ah car battery is sufficient to run two fluorescent $15 \mathrm{~W}$ bulbs overnight (dusk to dawn). A sealed, rechargeable 14Ah gel battery (or two 7Ah batteries) will power the same lights for approximately 4 hours, and their chargers are inexpensive (Figure 2).

With the addition of timers a series of lights at different locations can be timed to all go on and/or turn off at the same time or for sampling at different times during the night (to contrast early flying vs. late flying species or for maintaining a the charge on the battery over several nights. Timers were used by Monson (1997) to collect from one hour before to one hour after sunset.

The light pan trap method can be used to collect all orders of volant, nocturnal aquatic insects, but for caddisflies there is an additional important point to consider: collecting them dry and mounting them on pins is the best method to preserve the taxonomically informative wing colors and patterns imparted by the hairs (for detailed methods for collecting caddisflies dry see BlaHnik \& HolzENTHAL 2004). This is also true for other night flying insects with wing vestiture (e.g., moths also lose their 
scales in alcohol, but some to a lesser extent then their sister order Trichoptera).

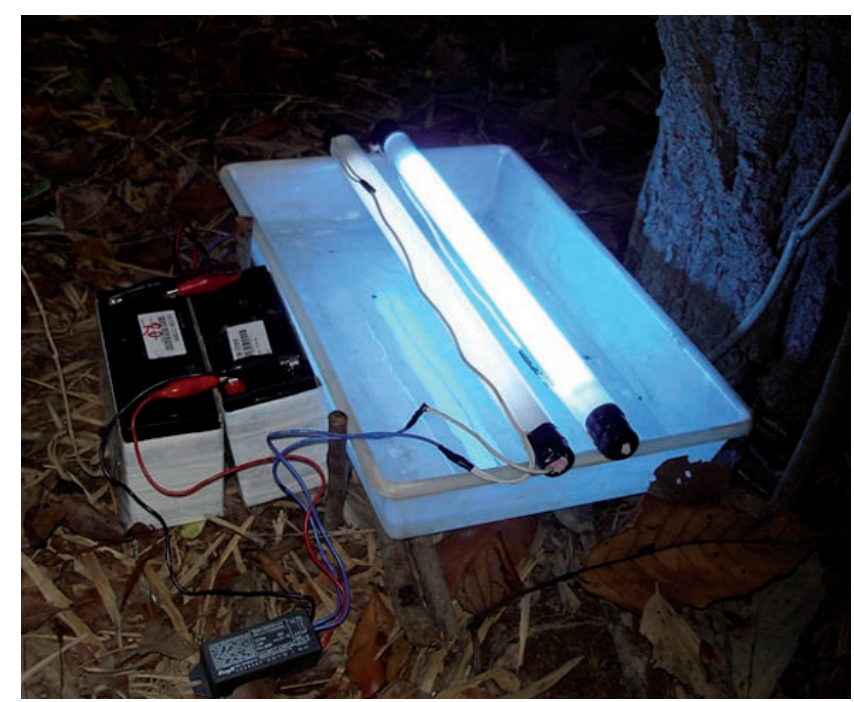

Figure 1. Light pan trap, the components of trap.

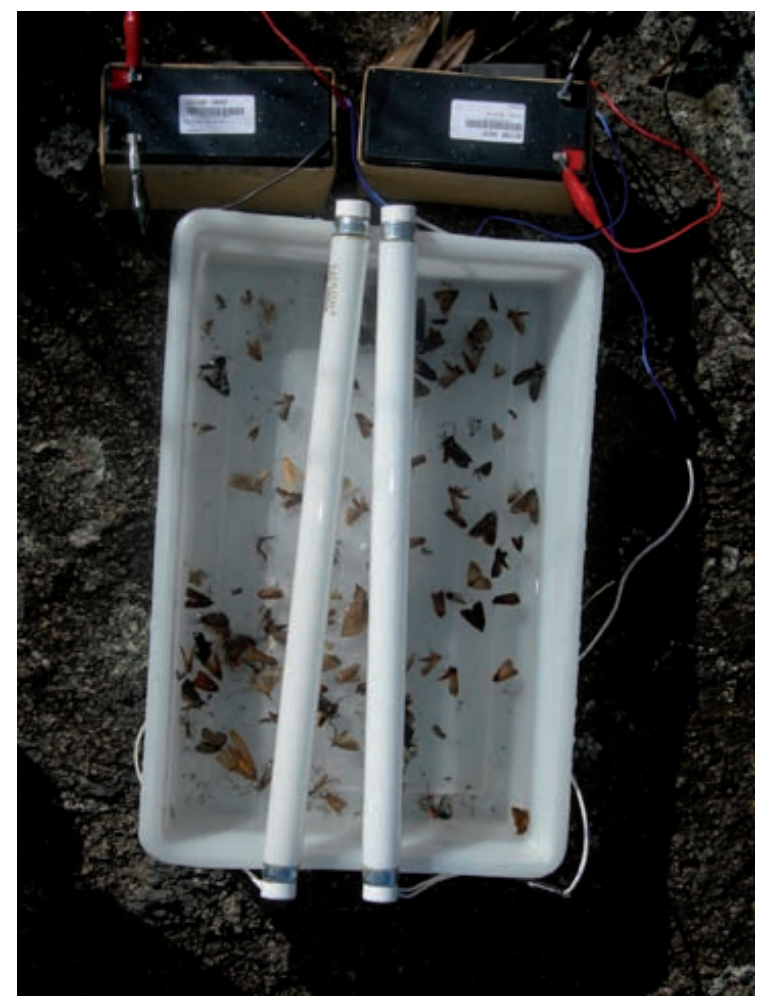

Figure 2. Light pan trap, after three collect hours in Pico dos Marins (Serra da Mantiqueira, Brazil).

Another disadvantage of the light pan trap method is the nonselective killing of Ephemeroptera. The immature winged stages (subimagoes) are attracted by UV light, often by the 1000s, but the taxonomic value of an alcohol preserved subimago is reduced because the pharate imago genitalia are not fully formed, cannot be dissected away from the subimago cuticle, or become damaged. With active collecting, the researcher has the opportunity to collect the subimago alive and keep it until metamorphosis. However, imago mayflies are also attracted to light pan traps.

Despite these disadvantages, the light pan trap can be used for others purposes, especially to increase the sampling effort and/or the number of collection sites. This trap is also extremely valuable for individuals who cannot be out at night to collect. For example, during an expedition in Acre State (Brazil), the first author used a light pan trap as the only tool because access to several streams was not possible during the night. Also, on mountains tops or other areas without trees or shrubs to hang a sheet, the light pan trap is a workable alternative. Similarly it is not affected by strong winds. On the other hand, in-flight of caddisflies to lights of any type is greatly reduced by cool temperatures (less that about $10-15^{\circ} \mathrm{C}$ ), in which case other techniques must be used, such as Malaise traps or "yellow pan traps" (with ethylene glycol as a preservative, see Myers \& RESH 1999).

Studies comparing the faunistic composition of Trichoptera communities and distinct land-use patterns (e.g., Collier et al. 1997; Houghton 2004, 2006) suggest that light-trapping has great potential as a tool for biomonitoring. Similarly, YosHimura \& MAETO (2004), in their comparison of sampling methods for bioindicator insects, showed that many families of Trichoptera and one family of Plecoptera were collected only by light trap surveys. These authors related their result to the diversity of aquatic microhabitats occupied by caddisfly larvae, and the difficulty of identifying and collecting them all with aquatic collecting methods. This is strong evidence of the importance of light trapping in surveys of aquatic insects, including Trichoptera.

For molecular phylogenetic studies, the collection of adults is preferable to larvae, because the former are more easily identified to species (KJER 2004), and the use of ethanol as a collecting and preserving agent is convenient and appropriate (in some cloning methods $96 \%$ ethanol is preferred). Thus, collecting adults by means of a pan trap is an excellent way to obtain material for later use in molecular studies.

In comparison to the CDC light trap, a commonly used light trap to catch nightflying insects, the light pan trap is more efficient in collecting aquatic insects, including chironomids, due to the attraction of these insects to UV. Moreover, the pan trap avoids damage to delicate specimens (e.g., caddisflies, mayflies, chironomids) caused by the moving fan blades of the CDC trap, and the immediate killing of specimens in alcohol by the light pan trap avoids the loss of captured specimens when the battery is spent.

In conclusion, the light pan trap is an excellent collecting device to maximize the number of collecting sites that can be sampled simultaneously and the number of specimens captured; to collect at sites that are difficult to access at night; to collect in treeless areas or under windy conditions where setting up a sheet is difficult; for quantitative collection of specimens for ecological studies; for the collection of specimens in alcohol for subsequent molecular studies; and for its low cost. However, whenever possible, a collection of pinned specimens should be made in parallel for those groups where it is more suitable (e.g., Trichoptera, Lepidoptera, Megaloptera, some Diptera, especially Culicidae).

\section{ACKNOWLEDGEMENTS}

We are grateful to the Aquatic Entomology team (FFCLRP/ USP) that used the light trap and improved its performance, and for their valuable suggestions on the manuscript. Dr. Ralph Holzenthal, University of Minnesota reviewed the manuscript and offered additional suggestions and information. This work was supported by a FAPESB and CNPq grants (ARC), FAPESB fellowship (RM).

\section{REFERENCES}

Blahnik, R.J. \& R.W. Holzenthal, 2004. Collection and curation of Trichoptera, with emphasis on pinned material. Nectopsyche, the Neotropical Trichoptera Newsletter, 1: 8-20.

Burks, B.D., H.H. Ross \& T.H. Frison, 1938. An economical, portable light for collecting nocturnal insects. Journal of Economic Entomology, 31: 317-8.

Collier, K.J., B.J. Smith \& B.R. Baillie, 1997. Summer light-trap catches of adult Trichoptera in hill-country catchments of contrasting land use, Waikato, New Zealand. New Zealand Journal of Marine and Freshwater Research, 31: 623-634. 
Gibb, T.J. \& C.Y. Oseto, 2006. Arthropod collection and identification: field and laboratory techniques. Boston, Academic Press. 311p.

Houghton, D.C., 2004. Utility of caddisflies (Insecta: Trichoptera) as indicators of habitat disturbance in Minnesota. Journal of Freshwater Ecology, 19: 97-108.

Houghton, D.C., 2006. The ability of common water quality metrics to predict habitat disturbance when biomonitoring with adult caddisflies (Insecta: Trichoptera). Journal of Freshwater Ecology, 21: 705-716.

Kjer, K.M., 2004. Collection and preparation of Trichoptera for DNA sequencing. Nectopsyche, the Neotropical Trichoptera Newsletter, 2: 11.

Marshall, S.A., R.S. Anderson, R.E. Roughly, V. Behan-Pelletier \& H.V. Danks, 1994. Terrestrial Arthropod Biodiversity: Planning a Study and Recommended Sampling Techniques. Bulletin of the Entomological Society of Canada, 26: 1-33.

Martin, J.E.H., 1977. The Insects and Arachnids of Canada, Part 1. Collecting, Preparing and Preserving Insects, Mites, and Spiders. Agriculture Canada, Publication 1643. 182p.

Monson, M.P., 1997. The caddisflies of the Lake Itasca region, Minnesota (Insecta: Trichoptera), p. 309-321. In: Holzenthal, R.W. \& O.S. Flint Jr. (Eds.). Proceedings of the 8th International Symposium on Trichoptera. Ohio, Ohio Biological Survey, Columbus. 496p.
Mulhern, T.D., 1942. New Jersey mechanical trap for mosquito surveys. New Jersey Agricultural Experiment Station, 421: $1-8$.

Myers, M.J. \& V.R. Resh, 1999. Use of pan traps to collect adult Trichoptera in high desert spring habitats of California, USA, p. 259-267. In: Malicky, H. \& P. Chantaramongkol (Eds.). Proceedings of the 9th International Symposium on Trichoptera. Chiang Mai, Thailand, Faculty of Science, Chiang Mai University. 479p.

Peterson, A., 1964. Entomological Techniques: How to Work with Insects, 10th Ed. Michigan, Edwards Brothers, Inc. Ann Arbor Michigan. 435p.

Steyskal, G.C., W.L. Murphy \& E.M. Hoover (Eds.). 1986. Insects and mites: Techniques for collection and preservation. U.S. Dept. of Agriculture, Miscellaneous Publications No. 1443. $103 p$.

Sudia, W.D. \& R.W. Chamberlain, 1962. Battery operated light trap, an improved model. Mosquito News, 22: 126-129.

Yoshimura, M. \& K. Maeto, 2004. Comparison of sampling methods for aquatic insect indicators of forest condition in terms of collection efficiency. Bulletin of Forestry and Forest Products Research Institute, 3: 213-219.

Recebido em: 23/o8/2011

Aceito em: 27/03/2012

Como citar este artigo:

Calor, A.R. \& R. Mariano, 2012. UV Light Pan Traps for Collecting Aquatic Insects, 5(2): 164-166.

Acessível em: http://www.periodico.ebras.bio.br/ojs/index.php/ebras/article/view/187
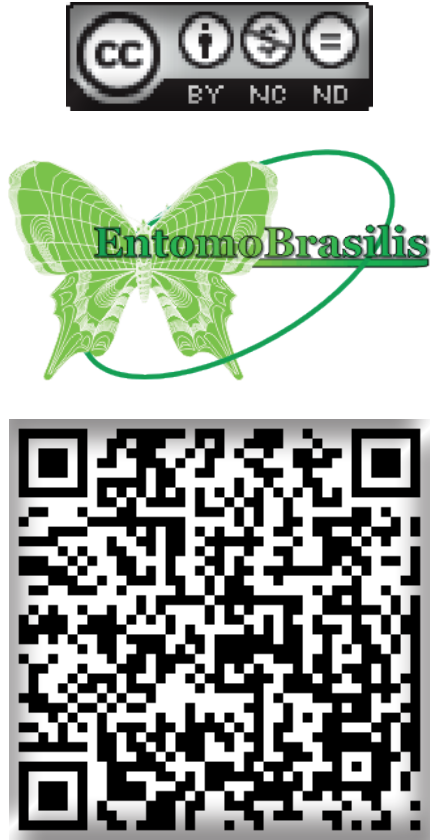